Article

\title{
Greener Synthesis of Pristane by Flow Dehydrative Hydrogenation of Allylic Alcohol Using a Packed-Bed Reactor Charged by $\mathrm{Pd} / \mathrm{C}$ as a Single Catalyst
}

\author{
Takayoshi Kasakado ${ }^{1}$, Yuki Hirobe ${ }^{2}$, Akihiro Furuta ${ }^{2}$, Mamoru Hyodo ${ }^{1}$, Takahide Fukuyama ${ }^{2, *}$ \\ and Ilhyong Ryu 1,3,* \\ 1 Organization for Research Promotion, Osaka Prefecture University, Sakai, Osaka 599-8531, Japan; \\ t_kasakado@c.s.osakafu-u.ac.jp (T.K.); hyodo_mam@c.s.osakafu-u.ac.jp (M.H.) \\ 2 Department of Chemistry, Osaka Prefecture University, Sakai, Osaka 599-8531, Japan; \\ ykhirobe@gmail.com (Y.H.); akihirofuruta5@gmail.com (A.F.) \\ 3 Department of Applied Chemistry, National Yang Ming Chiao Tung University (NYCU), \\ Hsinchu 30010, Taiwan \\ * Correspondence: fukuyama@c.s.osakafu-u.ac.jp (T.F.); ryu@c.s.osakafu-u.ac.jp (I.R.)
}

\section{check for} updates

Citation: Kasakado, T.; Hirobe, Y.; Furuta, A.; Hyodo, M.; Fukuyama, T.; Ryu, I. Greener Synthesis of Pristane by Flow Dehydrative Hydrogenation of Allylic Alcohol Using a Packed-Bed Reactor Charged by $\mathrm{Pd} / \mathrm{C}$ as a Single Catalyst. Molecules 2021, 26, 5845. https://doi.org/ $10.3390 /$ molecules 26195845

Academic Editors: Wei Zhang and Asunción Barbero

Received: 31 July 2021

Accepted: 23 September 2021

Published: 27 September 2021

Publisher's Note: MDPI stays neutral with regard to jurisdictional claims in published maps and institutional affiliations.

Copyright: (c) 2021 by the authors. Licensee MDPI, Basel, Switzerland. This article is an open access article distributed under the terms and conditions of the Creative Commons Attribution (CC BY) license (https:// creativecommons.org/licenses/by/ $4.0 /)$.

\begin{abstract}
Our previous work established a continuous-flow synthesis of pristane, which is a saturated branched alkane obtained from a Basking Shark. The dehydration of an allylic alcohol that is the key to a tetraene was carried out using a packed-bed reactor charged by an acid-silica catalyst (HO-SAS) and flow hydrogenation using molecular hydrogen via a Pd/C catalyst followed. The present work relies on the additional propensity of $\mathrm{Pd} / \mathrm{C}$ to serve as an acid catalyst, which allows us to perform a flow synthesis of pristane from the aforementioned key allylic alcohol in the presence of molecular hydrogen using Pd/C as a single catalyst, which is applied to both dehydration and hydrogenation. The present one-column-two-reaction-flow system could eliminate the use of an acid catalyst such as HO-SAS and lead to a significant simplification of the production process.
\end{abstract}

Keywords: flow dehydration; flow hydrogenation; Pd on carbon; dual-function catalyst; pristane

\section{Introduction}

Pristane, 2,6,10,14-tetramethylpentadecane 3, is a saturated branched alkane obtained from Basking Sharks [1,2], and is known to induce autoimmune diseases in rodents. Pristane, however, is now being widely used as an adjuvant for monoclonal antibody production [3-5]. In 2007, the Fukase group reported the flow/batch combined synthesis of pristane 3 via a two-step procedure with allylic alcohol $\mathbf{1}$ as a key component. Flow dehydration was performed by using a stoichiometric $\mathrm{p}-\mathrm{TsOH}$. The resultant tetraene 2 can be reduced to pristane 3 in a batch flask using molecular hydrogen with Pd on carbon $(\mathrm{Pd} / \mathrm{C})$ as the catalyst [6]. To realize a greener process, the flow dehydration protocol that employs a stoichiometric amount of $p$-TsOH must be avoided. Then, we focused on silica-supported sulfonic acids (SAS) $[7,8]$, for the flow dehydration step. Consequently, we found that the use of hydroxy-functionalized sulfonic acid silica, HO-SAS [9-11], for flow-dehydration worked well. Combined with the flow hydrogenation using $\mathrm{Pd} / \mathrm{C}$, we completed an acid waste-free flow synthesis of pristane (Scheme 1) [10]. Since Pd/C often causes dehydrative hydrogenation of allylic alcohols [12-17], we were curious as to whether pristane 3 could be synthesized using only a $\mathrm{Pd} / \mathrm{C}$ catalyst. In this communication, we are pleased to report a simple protocol for the flow synthesis of pristane using $\mathrm{Pd} / \mathrm{C}$ as a single catalyst in a dual function, which avoids the need to use an acid catalyst. We believe that the present flow protocol would be useful in designing a simplified flow-production process of pristane. It should be stated that, although flow hydrogenations of a variety of organic compounds have widely been developed [18-25], there were no reports on flow dehydrative hydrogenation of allylic alcohols before this work. 
Our previous work: double catalysts in flow (ref. 10)

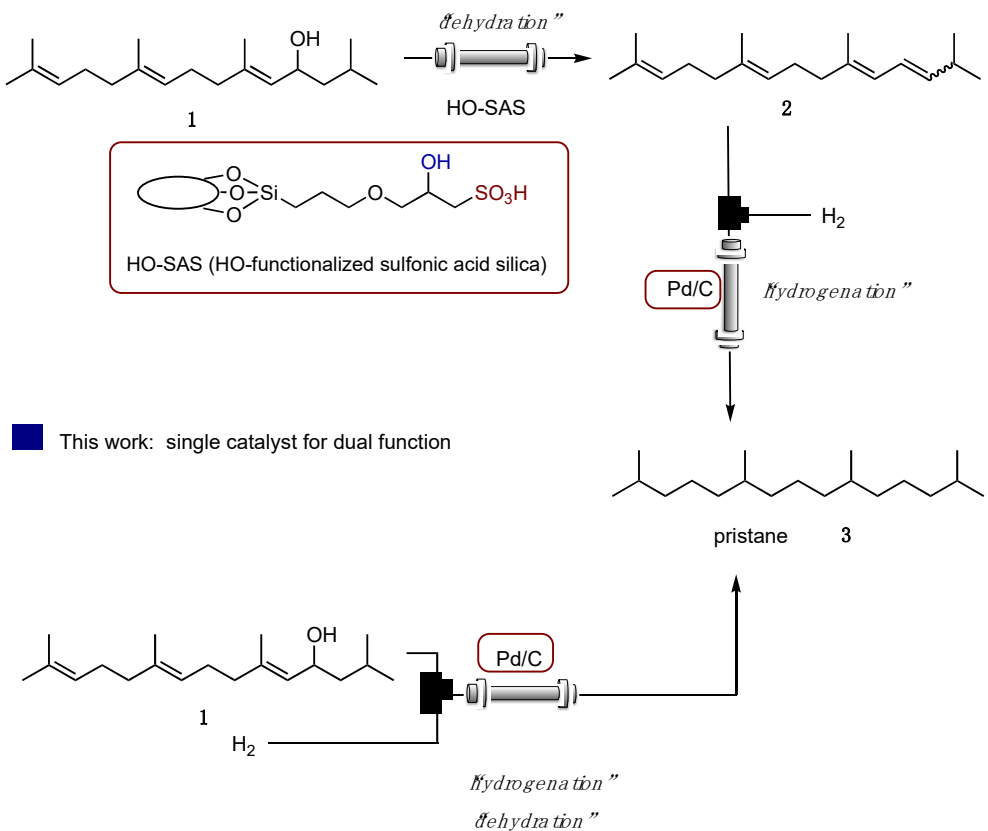

Scheme 1. Concise flow synthesis of pristane using $\mathrm{Pd} / \mathrm{C}$ as a single catalyst with a dual function.

\section{Results and Discussion}

We started with a batch reaction of triene-type alcohol 1 . As expected, when the reaction of $1(0.5 \mathrm{mmol})$ was carried out in the presence of $10 \% \mathrm{Pd} / \mathrm{C}(20 \mathrm{mg}, 0.02 \mathrm{mmol}$ of $\mathrm{Pd})$ in ethyl acetate as a solvent under atmospheric pressure of $\mathrm{H}_{2}$ at room temperature for $16 \mathrm{~h}$, the desired pristane 3 was obtained in a 30\% yield, together with saturated alcohol $4(48 \%)$ (Table 1, entry 1). When we used $\mathrm{Pd} / \mathrm{Al}_{2} \mathrm{O}_{3}$ instead of $\mathrm{Pd} / \mathrm{C}$, the reaction gave alcohol 4 in a $92 \%$ yield along with a trace amount of pristane 3 (Table 1, entry 2). These results strongly suggest that the $\mathrm{Pd} / \mathrm{C}$ catalyst has an exceptional ability to reduce an allyl alcohol moiety to pristane 3, which was consistent with results reported by other groups [10-15]. Under harsh conditions that included higher temperature $\left(90^{\circ} \mathrm{C}\right)$ and higher pressure $(10 \mathrm{~atm})$, the yield of $\mathbf{4}$ was increased, but that of $\mathbf{3}$ did not change (Table 1, entry 3 ).

Table 1. Batch synthesis of pristane 3 by dehydrative hydrogenation of $\mathbf{1}$ using a Pd/C Catalyst under a $\mathrm{H}_{2}$ atmosphere.

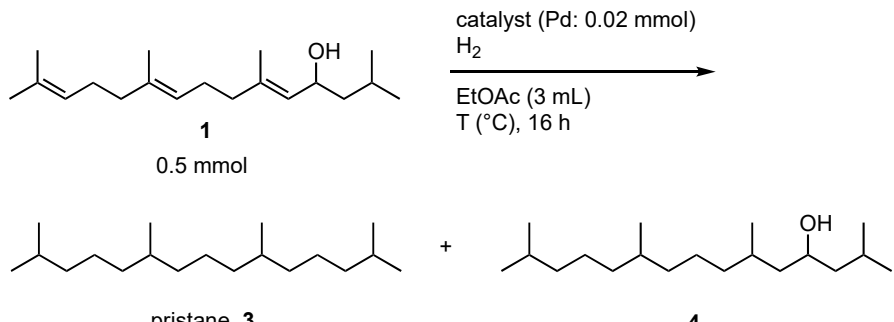

\begin{tabular}{|c|c|c|c|c|c|c|}
\hline \multirow{2}{*}{ Entry } & \multirow{2}{*}{ Catalyst (mg) } & \multirow{2}{*}{$\mathrm{T}\left({ }^{\circ} \mathrm{C}\right)$} & \multirow{2}{*}{$\begin{array}{c}\mathrm{H}_{2} \text { Pressure } \\
\text { (atm) }\end{array}$} & \multicolumn{2}{|c|}{ Pristane 3} & \multirow{2}{*}{4 Yield (\%) } \\
\hline & & & & Yield (\%) & Purity (\%) & \\
\hline 1 & $10 \% \mathrm{Pd} / \mathrm{C}(20)$ & $\mathrm{rt}$ & 1 & 30 & 99 & 48 \\
\hline 2 & $5 \% \mathrm{Pd} / \mathrm{Al}_{2} \mathrm{O}_{3}(40)$ & $\mathrm{rt}$ & 1 & Trace & - & 92 \\
\hline 3 & $10 \% \mathrm{Pd} / \mathrm{C}(20)$ & 90 & 10 & 30 & 98 & 63 \\
\hline
\end{tabular}


Despite the low yield, the results of the batch reaction confirmed that pristane 3 was formed from 1 via the use of a single catalyst, $\mathrm{Pd} / \mathrm{C}$. Nevertheless, the comparable selectivity of $\mathbf{3} / \mathbf{4}$ obtained by a batch reaction was rather disappointing. Next, we examined the flow dehydration/hydrogenation sequence, which improved the ratio of $3 / 4$ dramatically (Scheme 2). Thus, when an AcOEt solution of 1 was mixed with $\mathrm{H}_{2}$ (13 atm) using a static mixer ( $500 \mu \mathrm{m}$ i.d.) followed by passage through a column reactor $(4 \mathrm{~mm}$ i.d., $15 \mathrm{~cm}$ length) packed with $\mathrm{Pd} / \mathrm{C}(575 \mathrm{mg}, 0.54 \mathrm{mmol}$ of $\mathrm{Pd})$ at $90{ }^{\circ} \mathrm{C}$, to our surprise, the reaction gave pristane 3 as the major product in a 59\% yield along with an $18 \%$ yield of alcohol 4 with only a $30 \mathrm{sec}$ residence time. Heating was important, since the flow reaction at room temperature gave low yields of $3(15 \%)$ and $4(3 \%)$. We speculated that the use of a packed-column flow reactor ensured larger catalyst/substrate ratios which brought a high contact frequency between the substrate and catalyst to cause the efficient dehydrative hydrogenation of an allyl alcohol moiety to give pristane 3 .

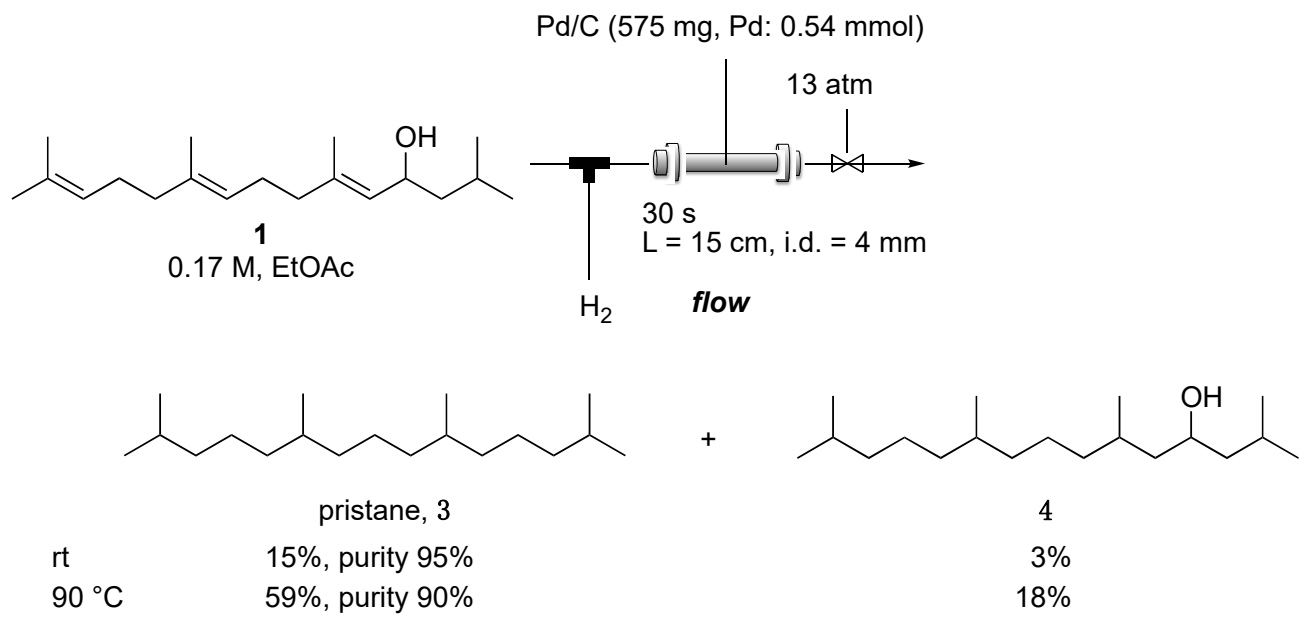

Scheme 2. Flow synthesis of pristane 3 by dehydrative hydrogenation of 1 using a Pd/C catalyst under a $\mathrm{H}_{2}$ atmosphere.

The flow procedure resulted in excellent selectivity over the batch reaction. Then, we decided to use model compound 5 to see if the product selectivity could be further improved (Scheme 3). When the reaction of $5(0.5 \mathrm{mmol})$ was carried out in the presence of $10 \% \mathrm{Pd} / \mathrm{C}(20 \mathrm{mg})$ in AcOEt under atmospheric $\mathrm{H}_{2}$ at room temperature for $24 \mathrm{~h}$, the desired alkane 6 was obtained as a major product, together with hydrogenated alcohol 7 and ketone 8 in a ratio of $6 / 7 / 8=64 / 16 / 20$ (by a GC analysis). Interestingly, the addition of a $10 \%$ volume of $i-\mathrm{PrOH}$ to AcOEt improved the formation ratio of alkane $6(6 / 7 / 8=$ $78 / 10 / 12)$. Since ketone 8 was also detected, we, then, carried out time course experiments. Interestingly, the reaction in AcOEt as a sole solvent did not proceed for the first $30 \mathrm{~min}$. After $1 \mathrm{~h}$, around $20 \%$ of alcohol 7 was formed, and, then, alkane 6 was rapidly formed (Scheme 3a). On the other hand, the reaction with EtOAc/i-PrOH was started within $30 \mathrm{~min}$ and ended in $1 \mathrm{~h}$, which gave a higher yield of 6 (Scheme $3 \mathrm{~b}$ ). These results suggest that the reaction had an induction period and the addition of i-PrOH and initially formed secondary alcohol 7 contributed to generate $\mathrm{H}-\mathrm{Pd}$ species prior to the reaction of molecular hydrogen with Pd. Since ketone 8 was formed after alcohol $\mathbf{7}$ was formed, the transfer hydrogenation from the secondary alcohol 7 to 8 [26-28] was more likely than olefin-isomerization of the allylic alcohol 5 [29-32]. 


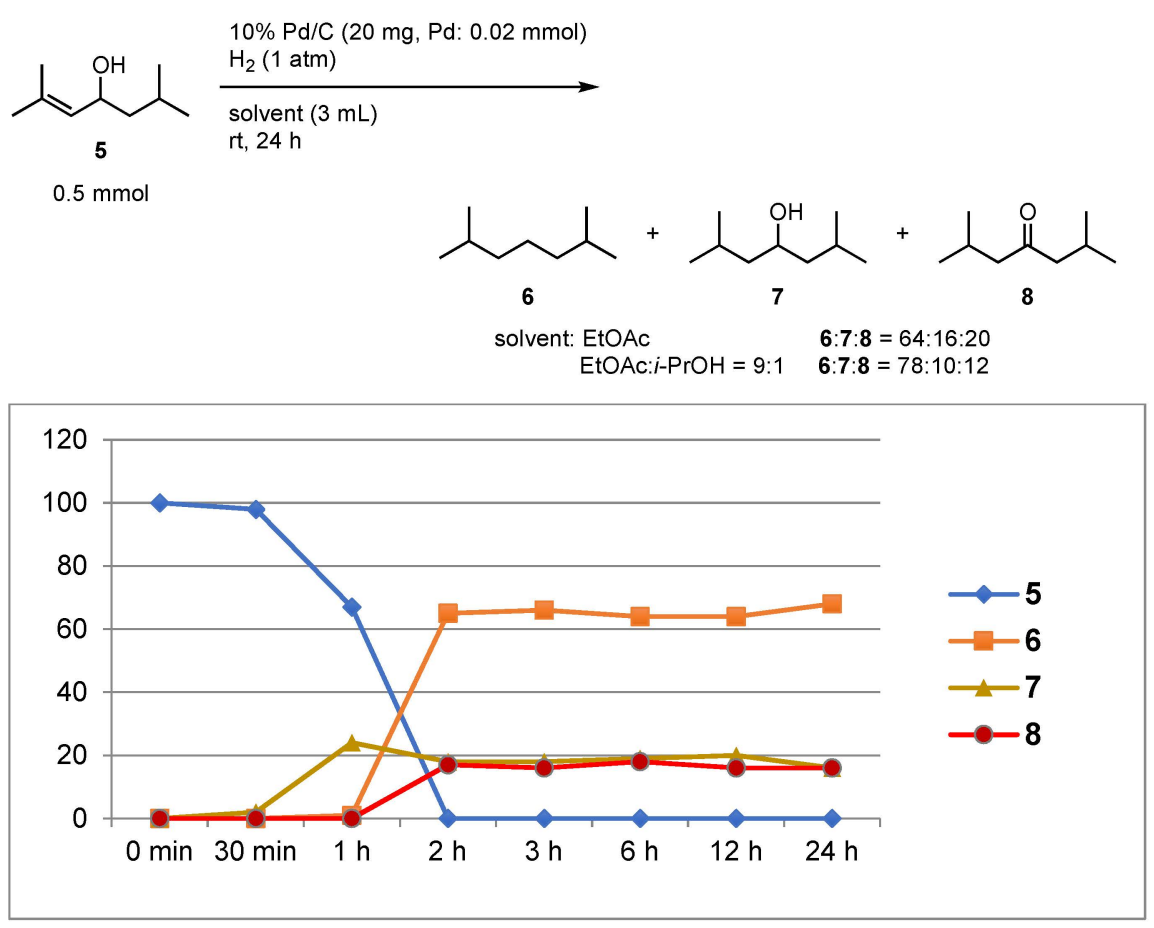

(a) Time course experiment for the reaction in EtOAc.

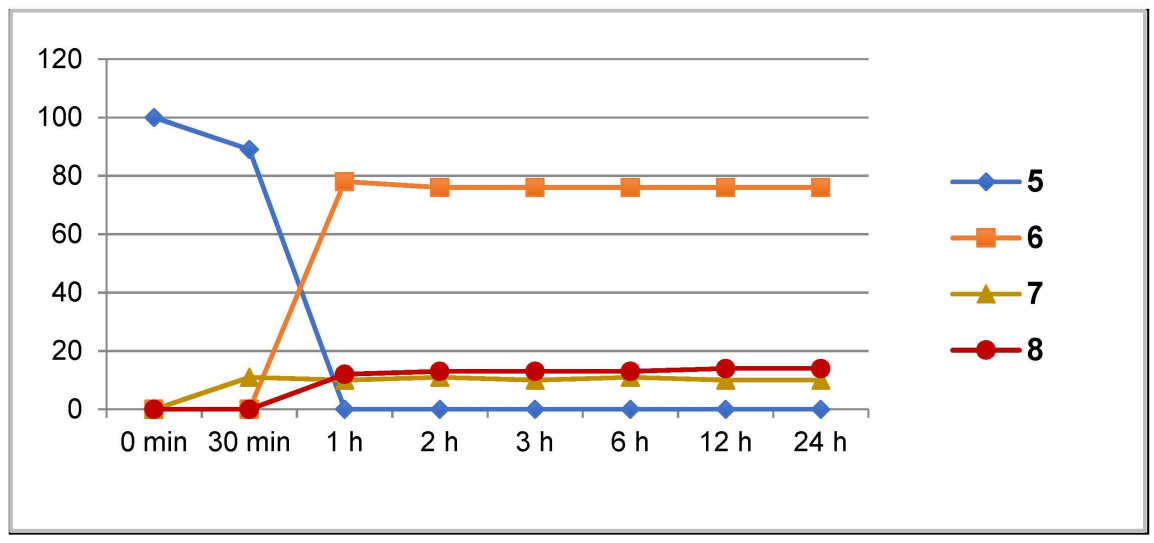

(b) Time course experiment for the reaction EtOAc/i-PrOH.

Scheme 3. Batch hydrogenation reaction of a model compound 5 using $\mathrm{Pd} / \mathrm{C}$ as a catalyst using EtOAc and EtOAc/i-PrOH (9:1) as solvent and time course experiments. (a) Time course experiment for the reaction in EtOAc. (b) Time course experiment for the reaction EtOAc/i-PrOH.

It seems quite difficult to speculate the mechanism of Pd-catalysis; however, one possible mechanism is shown in Scheme 4. The transfer hydrogenation would produce a Pd-H species. Allylic alcohol 5 coordinated to the Pd catalyst in both the $\mathrm{C}-\mathrm{C}$ double bond and hydroxy group. Then, the dehydration reaction proceeded to give a diene $[33,34]$. Finally, the diene was hydrogenated by Pd/C to give alkane 6 . It should be noted that the addition of $\mathrm{Et}_{3} \mathrm{~N}$ inhibited the present dehydrated hydrogenation and only hydrogenated alcohol 7 was formed in $96 \%$ yield. This suggests that a base such as $\mathrm{Et}_{3} \mathrm{~N}$ deactivated the acid functionality of $\mathrm{Pd} / \mathrm{C}$. 


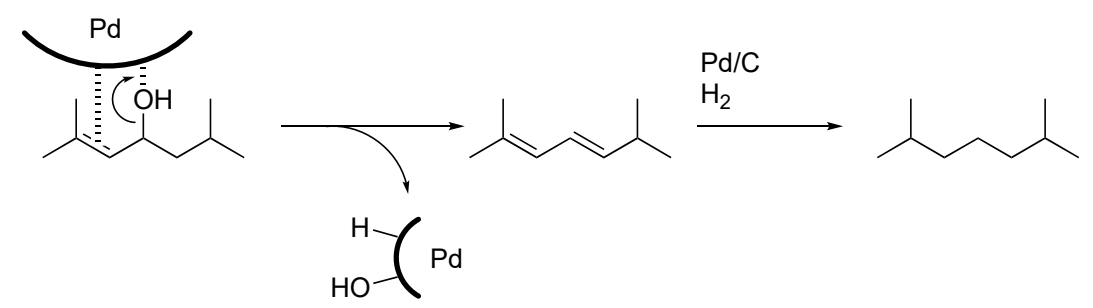

Scheme 4. A possible mechanism.

Since the addition of $i$-PrOH improved the product selectivity, we, finally, examined the flow synthesis of pristane 3 using a mixed solvent of AcOEt and $i$-PrOH (10 vol\%) under continuous flow conditions (Scheme 5). To our delight, the flow conditions worked far better to give pristane 3 in an improved yield of 71\% with a reduced yield of alcohol 4 $(10 \%)$, whose result was in good agreement with the model reaction.

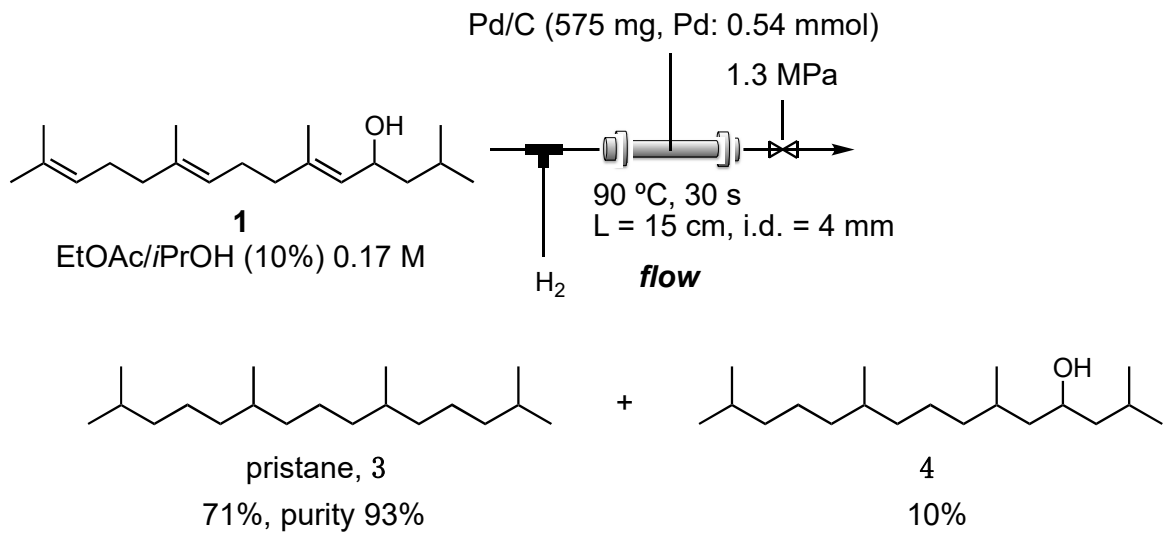

Scheme 5. Flow synthesis of pristane 3 by dehydrative reduction in $\mathbf{1}$ using $\mathrm{Pd} / \mathrm{C}$ catalyst and $\mathrm{AcOEt} / i-\mathrm{PrOH}$ as a solvent under a $\mathrm{H}_{2}$ atmosphere.

\section{Materials and Methods}

\subsection{General}

The ${ }^{1} \mathrm{H}$ NMR spectra were recorded using JEOL ECS-400 (400 MHz) spectrometers in $\mathrm{CDCl}_{3}$ and were referenced at $7.26 \mathrm{ppm}$ for $\mathrm{CHCl}_{3}$. The ${ }^{13} \mathrm{C} \mathrm{NMR}$ spectra were recorded using JEOL ECS-400 (100 MHz) spectrometers in $\mathrm{CDCl}_{3}$ referenced at $77.0 \mathrm{ppm}$. Chemical shifts were reported in parts per million $(\delta)$. Splitting patterns were indicated as follows: br, broad; s, singlet; $d$, doublet; $t$, triplet; $m$, multiplet. GC analysis was performed on a Shimadzu GC-2014 instrument equipped with an FID detector using a J\&W Scientific (Hongkong, China) DB-1 column under the following conditions: initial oven temperature was held at $60{ }^{\circ} \mathrm{C}$ for $5 \mathrm{~min}$, the first ramp was $20^{\circ} \mathrm{C} / \mathrm{min}$ to $250{ }^{\circ} \mathrm{C}$, which was held for $5 \mathrm{~min}$. The products were purified by flash column chromatography on silica gel (KANTO

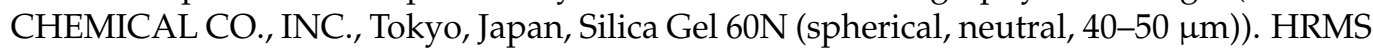
spectra were recorded on BRUKER micrOTOF-II. Allylic alcohol 1 was prepared according to a previously established procedure found in the literature [6]. We purchased 10\% Pd/C from Sigma-Aldrich Co. LLC. (St. Louis, MO, USA). (10\% Pd on carbon, average particle size of $15 \mu \mathrm{m})$ and used it as received. Stainless steel columns $(4.0 \mathrm{~mm}$ i.d. $\times$ $50 \mathrm{~mm}$ or $150 \mathrm{~mm}$ ) were purchased from GL Sciences Inc (Tokyo, Japan). The column reactor and microtube were connected with PEEK fittings (GL Sciences Inc., 1/16" ). The micromixer (500 $\mu \mathrm{m}$ i.d.) was purchased from GL Sciences. A back-pressure regulator was purchased from DFC Inc. (Woodland, CA, USA). The solution was introduced into the flow microreactor system using an HPLC pump, PU714 (GL Sciences Inc.). 


\subsection{Typical Procedure for the Batch Synthesis of 2,6-Dimethylheptane 6}

To a $10 \mathrm{~mL}$ glass flask, 2,6-dimethyl-2-hepten-4-ol 5 (0.5 mmol, $71 \mathrm{mg})$ and $\mathrm{Pd} / \mathrm{C}$ $(20 \mathrm{mg})$ were added along with a solvent (AcOEt, $3 \mathrm{~mL}$ ). The mixture was stirred at room temperature under $\mathrm{H}_{2}(1 \mathrm{~atm})$. After the reaction, the reaction mixture was filtered to remove $\mathrm{Pd} / \mathrm{C}$ and an aliquot of the solution was applied to GC analysis.

\subsection{Typical Procedure for the Batch Synthesis of Pristane 3}

Allylic alcohol 1 ( $0.5 \mathrm{mmol}, 139 \mathrm{mg}), \mathrm{Pd} / \mathrm{C}(20 \mathrm{mg})$ and EtOAc $(3 \mathrm{~mL})$ were placed in a $10 \mathrm{~mL}$ glass flask. The mixture was stirred at room temperature for $16 \mathrm{~h}$ under $\mathrm{H}_{2}$ (1 atm). After the reaction, the solvent was evaporated and the residue was filtered through a silica-gel pad and washed with $n$-hexane to give pristane (3) $(39.7 \mathrm{mg}$, yield $30 \%$, purity $100 \%$ ). The silica-gel pad was washed with EtOAc to give 4 (68.8 mg, yield $48 \%$ ).

\subsection{Procedure for the Flow Synthesis of Pristane 3}

Allylic alcohol $1(477 \mathrm{mg})$ was dissolved in EtOAc $(10 \mathrm{~mL})$ and pumped using an HPLC pump (flow rate $=0.5 \mathrm{~mL} / \mathrm{min}$ ). The $\mathrm{H}_{2}$ gas (flow rate $=2.6 \mathrm{~mL} / \mathrm{min}$ ) was supplied through a mass flow controller. Both the solution of $\mathbf{1}$ and hydrogen gas were introduced to a T-shaped mixer (i.d. $500 \mu \mathrm{m}$ ), and the resultant mixture was then introduced into a stainless steel column (inner volume: $1.44 \mathrm{~mL}, 4.0 \mathrm{~mm}$ i.d. $\times 150 \mathrm{~mm}$ ) filled with a Pd/C catalyst $(595 \mathrm{mg})$ with an outlet that was connected to a back-pressure regulator (1.3 MPa). The solution eluted during the first $10 \mathrm{~min}$ was discarded. The remaining solution was collected for $6 \mathrm{~min}$ in a glass flask, and the solvent was evaporated. The crude product was applied to silica-gel column chromatography and the fractions eluted with $n$-hexane gave pristane (3) with inseparable by-products ( $96 \mathrm{mg}$, yield $71 \%$, purity $93 \%$ (determined by GC)). The fraction eluted with ethyl acetate gave saturated alcohol 4 (14 mg, yield 10\%).

2,6,10,14-Tetramethylpentadecane (pristane, 3) (see Supplementary Materials)

Colorless oil; ${ }^{1} \mathrm{H}$ NMR $\left(\mathrm{CDCl}_{3}, 400 \mathrm{MHz}\right) \delta 1.58-1.44(\mathrm{~m}, 2 \mathrm{H}), 1.40-1.00(\mathrm{~m}, 20 \mathrm{H})$,

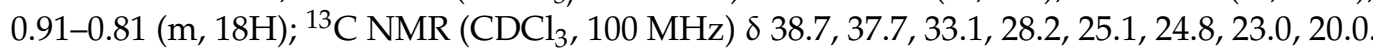

2,6,10,14-Tetramethylpentadecan-4-ol (4) (see Supplementary Materials)

Colorless oil; ${ }^{1} \mathrm{H}$ NMR $\left(\mathrm{CDCl}_{3}, 400 \mathrm{MHz}\right) \delta 3.83-3.70(\mathrm{~m}, 1 \mathrm{H}), 1.83-1.70(\mathrm{~m}, 1 \mathrm{H}), 1.70$ $1.00(\mathrm{~m}, 20 \mathrm{H}), 0.80-1.00(\mathrm{~m}, 18 \mathrm{H}) ;{ }^{13} \mathrm{C}$ NMR $\left(\mathrm{CDCl}_{3}, 100 \mathrm{MHz}\right) \delta 68.1,67.7,47.7,47.2,46.0$, $45.9,45.7,45.6,39.4,38.3,37.4,37.3,37.3,37.1,37.0,32.9,29.7,29.6,29.3,28.1,24.9$, 24.7, 24.6, $24.3,23.7,23.5,22.8,22.7,22.3,20.5,20.4,19.8,19.7,19.4$. HRMS: $m / z$ calcd for $\mathrm{C}_{19} \mathrm{H}_{40} \mathrm{NaO}$ $\left(\mathrm{M}^{+}+\mathrm{Na}\right)$ 307.2977, found 307.2952.

\section{Conclusions}

We showed that, in the presence of dihydrogen and a catalytic amount of $\mathrm{Pd} / \mathrm{C}$, the dehydrative hydrogenation of triene-alcohol 1 proceeded, in a batch flask, to give the desired pristane 3 and saturated alcohol $\mathbf{4}$ in a nearly comparable ratio. Interestingly, when continuous flow conditions were applied, a dramatic preference of $\mathbf{3}$ over $\mathbf{4}$ was observed by as much as $7 / 1$. Larger catalyst/substrate ratios, ensured by the use of a packed-column reactor, were likely to cause the efficient dehydrative hydrogenation of an allyl alcohol moiety by reacting with more abundant active $\mathrm{Pd}-\mathrm{H}$ species. The flow reaction proceeded quickly at $90{ }^{\circ} \mathrm{C}$ and needed only $30 \mathrm{~s}$ of residence time, which established the efficacy of the consecutive flow reaction for production compared with a batch reaction. Such a strong boost by a flow system is a novel result, which could, undoubtedly, lead to a greener and inexpensive production of pristane and some other target compounds. This one-column-two-reaction-flow system could eliminate the use of an acid catalyst such as HO-SAS, which also leads to a significant simplification of the facile production process for dehydrative hydrogenation of alkenyl alcohols.

Supplementary Materials: The following are available online. 
Author Contributions: Investigation: T.K., Y.H., A.F., M.H. writing original-draft preparation: T.F. writing-review and editing: I.R. All authors have read and agreed to the published version of the manuscript.

Funding: This work was supported by a project, JPNP14004, commissioned by the New Energy and Industrial Technology Development Organization (NEDO). This work was supported by a project, JPNP14004, commissioned by the New Energy and Industrial Technology Development Organization (NEDO). I.R. thanks the Center for Emergent Functional Matter Science at NYCU for the support.

Institutional Review Board Statement: Not applicable.

Informed Consent Statement: Not applicable.

Data Availability Statement: Not applicable.

Conflicts of Interest: The authors declare no conflict of interest.

\section{References}

1. Matthews, L.H. Reproduction in the basking shark, Cetorhinus maximus (Gunner). Philos. Trans. R. Soc. London Ser. B 1950, 234, 247-316.

2. Parker, H.W.; Scott, F.C. Age, size and vertebral calcification in the basking shark, Cetorhinus maximus (Gunnerus). Zool. Meded. 1965, 40, 305-319.

3. Satoh, M.; Richards, H.B.; Shaheen, V.M.; Yoshida, H.; Shaw, M.; Naim, J.O.; Wooley, P.H.; Reeves, W.H. Widespreadsusceptibility among inbred mouse strains to the induction of lupus auto- antibodies by pristane. Clin. Exp. Immunol. 2000, 121, 399-405. [CrossRef] [PubMed]

4. Holmdahl, R.; Lorentzen, J.C.; Lu, S.; Olofsson, P.; Wester, L.; Holmberg, J.; Peterson, U. Arthritis induced in rats with nonimmunogenic adjuvants as models for rheumatoid arthritis. Immunol. Rev. 2001, 184, 184-204. [CrossRef] [PubMed]

5. Gado, K.; Silva, S.; Paloczi, K.; Domjan, G.; Falus, A. Mouse plasmacytoma: An experimental model of human multiple myeloma. Haematologica 2001, 86, 227-236. [PubMed]

6. Tanaka, K.; Motomatsu, S.; Koyama, K.; Tanaka, S.; Fukase, K. Large-scale synthesis of immunoactivating natural product, pristane, by continuous microfluidic dehydration as the key step. Org. Lett. 2007, 9, 299-302. [CrossRef]

7. Gholamzadeh, P.; Ziarani, G.M.; Lashgari, N.; Badiei, A.; Asadiatouei, P. Silica functionalized propyl sulfonic acid $\left(\mathrm{SiO}_{2}-\mathrm{Pr}-\mathrm{SO} \mathrm{H}_{3} \mathrm{H}\right)$ : An efficient catalyst in organic reactions. J. Mol. Catal. A Chem. 2014, 391, 208-222. [CrossRef]

8. Ziarani, G.M.; Lashgari, N.; Badiei, A. Sulfonic acid-functionalized mesoporous silica (SBA-Pr-SO $\left.{ }_{3} \mathrm{H}\right)$ as solid acid catalyst in organic reactions. J. Mol. Catal. A Chem. 2015, 397, 166. [CrossRef]

9. Furuta, A.; Fukuyama, T.; Ryu, I. Efficient flow Fischer esterification of carboxylic acids with alcohols using sulfonic acidfunctionalized silica as supported catalyst. Bull. Chem. Soc. Jpn. 2017, 90, 607-612. [CrossRef]

10. Furuta, A.; Hirobe, Y.; Fukuyama, T.; Ryu, I.; Manabe, Y.; Fukase, K. Flow dehydration and hydrogenation of allylic alcohols: Application to the waste-free synthesis of pristane. Eur. J. Org. Chem. 2017, 2017, 1365-1368. [CrossRef]

11. Kasakado, T.; Hyodo, M.; Furuta, A.; Kamardine, A.; Ryu, I.; Fukuyama, T. Flow Friedel-Crafts alkylation of 1-adamantanol with arenes using HO-SAS as an immobilized acid catalyst. J. Chin. Chem. Soc. 2020, 67, 2253-2257. [CrossRef]

12. Baltzly, R.; Buck, J.S. Catalytic debenzylation. The effect of substitution on the strength of the O-benzyl and N-benzyl Llinkages. J. Am. Chem. Soc. 1943, 65, 1984-1992. [CrossRef]

13. Simion, A.-M.; Arimura, T.; Simion, C. Reaction of cinnamaldehyde and derivatives with Raney Ni-Al alloy and $\mathrm{Al}$ powder in water. Reduction or oxido-reduction? Comptes Rendus Chim. 2013, 16, 476-481. [CrossRef]

14. Carless, H.A.; Malik, S.S. Synthesis of pseudo- $\alpha$-L-fucopyranose from toluene. J. Chem. Soc. Chem. Commun 1995, 2447-2448. [CrossRef]

15. Donaldson, W.A.; Sem, D.S.; Neumann, T.S. Preparation of (4'-hydroxyphenyl)cycloalkane compounds useful as selective agonists of the estrogen receptor beta isoform. PCT Patent 2015077611, 28 May 2015.

16. Uchibayashi, M. Studies on Steroids. XIV. Transformation of steroids by pseudomonas. Chem. Pharm. Bull. 1960, 8, 122-125. [CrossRef]

17. Sasaki, K.; Wakamatsu, T.; Matsumura, S.; Toshima, K. Synthesis of hexopyranosyl acetates and 2,3-disubstituted tetrahydropyrans via chemoselective hydrogenation of hex-2-enopyranosyl acetates. Tetrahedron Lett. 2006, 47, 8271-8274. [CrossRef]

18. Yu, T.; Jiao, J.; Song, P.; Nie, W.; Yi, C.; Zhang, Q.; Li, P. Recent progress in continuous-flow hydrogenation. ChemSusChem 2020, 13, 2876-2893. [CrossRef] [PubMed]

19. Cossar, P.J.; Hizartzidis, L.; Simone, M.I.; McCluskey, A.; Gordon, C.P. The expanding utility of continuous flow hydrogenation. Org. Biomol. Chem. 2015, 13, 7119-7130. [CrossRef] [PubMed]

20. Irfan, M.; Glasnov, T.N.; Kappe, C.O. Heterogeneous catalytic hydrogenation reactions in continuous-flow reactors. ChemSusChem 2011, 4, 300-316. [CrossRef]

21. Yoswathananont, N.; Nitta, K.; Nishiuchi, Y.; Sato, M. Continuous hydrogenation reactions in a tube reactor packed with Pd/C. Chem. Commun. 2005, 40-42. [CrossRef] 
22. Linares, N.; Hartmann, S.; Galarneau, A.; Barbaro, P. Continuous partial hydrogenation reactions by Pd/unconventional bimodal porous titania monolith catalysts. ACS Catal. 2012, 2, 2194-2198. [CrossRef]

23. Ouchi, T.; Battilocchio, C.; Hawkins, J.M.; Ley, S.V. Process intensification for the continuous flow hydrogenation of ethyl nicotinate. Org. Process Res. Dev. 2014, 18, 1560-1566. [CrossRef]

24. Spare, L.K.; Harman, D.G.; Aldrich-Wright, J.R.; Nguyen, T.V.; Gordon, C.P. Chemoselective flow hydrogenation approaches to diversify the cytotoxic tetrahydroepoxyisoindole carboxamide scaffold. Adv. Synth. Catal. 2018, 360, 1209-1217. [CrossRef]

25. Gardiner, J.; Nguyen, X.; Genet, C.; Horne, M.D.; Hornung, C.H.; Tsanaktsidis, J. Catalytic static mixers for the continuous flow hydrogenation of a key intermediate of linezolid (Zyvox). Org. Process. Res. Dev. 2018, 22, 1448-1452. [CrossRef]

26. Jerome, P.; Haribabu, J.; Bhuvanesh, N.S.P.; Karvembu, R. Pd(II)-NNN pincer complexes for catalyzing transfer hydrogenation of Ketones. ChemistrySelect 2020, 5, 13591-13597. [CrossRef]

27. Nisanci, B.; Dagalan, Z. A facile and highly efficient transfer hydrogenation of ketones and aldehydes catalyzed by palladium nanoparticles supported on mesoporous graphitic carbon nitride. J. Chem. Res. 2020, 44, 14-19. [CrossRef]

28. Mahato, S.K.; Ul Islam, R.; Acharya, C.; Witcomb, M.J.; Mallick, K. Polymer-stabilized palladium nanoparticles for the chemoselective transfer hydrogenation of $\alpha, \beta$-unsaturated carbonyls. single-step bottom-up approach. ChemCatChem 2014, 6, 1419-1426.

29. Hanna, S.; Wills, T.; Butcher, T.W.; Hartwig, J.F. Palladium-catalyzed oxidative dehydrosilylation for contra-thermodynamic olefin isomerization. ACS Catal. 2020, 10, 8736-8741. [CrossRef]

30. Ren, W.; Sun, F.; Chu, J.; Shi, Y. A Pd-catalyzed site-controlled isomerization of terminal olefins. Org. Lett. 2020, 22, 1868-1873. [CrossRef]

31. Maung, M.S.; Shon, Y.-S. Effects of noncovalent interactions on the catalytic activity of unsupported colloidal palladium nanoparticles stabilized with thiolate ligands. J. Phys. Chem. C 2017, 121, 20882-20891. [CrossRef]

32. Larionov, E.; Lin, L.; Guenee, L.; Mazet, C. Scope and mechanism in palladium-catalyzed isomerizations of highly substituted allylic, homoallylic, and alkenyl alcohols. J. Am. Chem. Soc. 2014, 136, 16882-16894. [CrossRef] [PubMed]

33. Huang, Y.-K.; Zhang, W.-Z.; Zhang, K.; Wang, W.-L.; Lu, X.-B. Carbon dioxide-promoted palladium-catalyzed dehydration of primary allylic alcohols: Access to substituted 1,3-dienes. Org. Chem. Front. 2021, 8, 941-946. [CrossRef]

34. Masuyama, Y.; Takahara, J.P.; Hashimoto, K.; Kurusu, Y. Palladium-catalyzed dehydration of propynyl alcohols with tin(II) chloride. J. Chem. Soc. Chem. Commun. 1993, 1219-1220. [CrossRef] 